\title{
Turo-Turismo Culture-Based Instructional Materials for SHS English
}

\author{
Ma. Vibeth C. Luga, EdD- ELT* \\ mavibeth.luga@deped.gov.ph \\ Department of Education, Research and Languages Adviser, Lourdes NHS, Panglao 6340, Philippines \\ Cebu Normal University, Osmeña Boulevard, Cebu City 6000, Philippines
}

\section{Abstract}

The full implementation of the Senior High School (SHS) poses a challenge in the provision of instructional materials (IMs), especially in the teaching of the competencies in the course, Reading and Writing Skills. This course specifically demands IMs for reading articles that would both engage the learners in the task and would cultivate their knowledge of culture and heritage to enhance learning experiences (Culatta, 2016; Anderson, 1977; Halliday, 1976; Vygotsky 1986). Furthermore, the Turo-Turismo Program compounds the need for IMs to be manifested in the course instruction. This study aimed at developing and utilizing the Turo-Turismo Culture-based IMs. The research respondents were the 88 SHS students chosen thru convenience sampling. These students were from Lourdes National High School in Panglao, Bohol which pilots the national implementation of the Turo-Turismo Program. This study employed a mixed method of both quantitative and qualitative designs. The validated and researcher-made pre-post-test was conducted to identify the proficiency level of students before and after the conduct of the culture-based activities. A needs analysis was done to identify the culture-based IMs to be included in the module. It was quantitatively based on the pre-test and qualitatively based on the encounter with the internal and external stakeholders during the SHS work immersion of the researcher. The findings of the pre-post-tests revealed that the culturebased activities improve the proficiency level of the students from foundations to advanced (high) or launch levels. This implied that the developed IMs were effective learning tools in improving the Reading and Writing Skills of the students.

Keywords: culture-based learning activity; instructional materials (IMs) development and implementation; Turo-Turismo Program; Reading and Writing Skills competencies, Senior High School (SHS) English

\section{Introduction}

The Instructional materials (IMs) for the senior high school continue to be a bottleneck to an efficient implementation of the K to 12 program (David and Albert, 2012). Supply side factor was one of the reasons pointed out by FLEMMS (Functional Literacy, Education and Mass Media Survey) that impedes DepEd in realizing the 100 percent Education For All (EFA) goal of achieving quality education. This is when instructional materials do not meet the demands in the educational pedagogy.

The gap continues to thrive if the issue on IMs will not be properly addressed specially in the newly installed level of Philippine educational system which is the senior high school level. The Senior High School level compounds the demand for adequate and appropriate IMs especially in the course Reading and Writing Skills.

Despite the Philippines' high literacy rate, these potential applicants lack skills in reading and writing as life-long learning or "survival" skills. The essence of functional literacy is not just a simple ability to read and write, and extract meaning from it, but it also requires the ability to think with a higher abstraction (Luz, 2007). On the other hand, for workers to have a quality written output, quality reading instruction at school must be the priority. It is more costly indeed for a government to raise a generation of non-readers (Selangan, 2015).

Reading and writing are the skills that are given a high value by the employers in other countries to the point of allotting budget on training employees for harnessing the workers' communicative aspects. These skills when used in the workplace and when used effectively prove a rewarding endeavor to the workers acquiring such skills. Furthermore, reading and writing skills even ranked first and fourth respectively on the nine lists of essential skills needed in the workplace, higher than oral communication skill (Hosking, 2014 \& WEM, 2016). 
A 21 st century learner in the $\mathrm{K}$ to 12 , and most significantly a student under the tourism-centered program of SHS considers reading and writing an impending investment. Tourism feeds Philippines for about eight percent of the country's economy (Department of Tourism, 2016). This impact of tourism in the country has paved way to the implementation of a tourism-based program in the senior high school called "Turo-Turismo-Based Program". A senior high school in Panglao which is Bohol's seat of tourism nationally pilots this SHS program.

Turo-turismo program recognizes the three pillars of growth: agriculture, ICT, and tourism. The latter is the LGU's first step to the envisioned growth, where the education sector plays a crucial role for this growth to flourish and sustain. Thus, the graduates of senior high school under the Turo-turismo program must exhibit the 21 st century skills as well as the tourism values expected of them to be consistently productive workers in their own field. Communication and sociocultural aspects of these skills are the highlights of this study.

English communication competence is one of the aces of Philippines when accommodating visitors. Nelson Mandela's quote "...talk to a man in his language, that goes to his heart" substantiates the Filipinos' capability to communicate to the tourists' heart through English.

However, this positive English language perception of tourists to Filipinos does not pose complacence in terms of job attainment nor job sustainability. Employees demand higher expectations on the applicant's English skills which impede learners to land a job especially in the tourism industry. Job sustainability particularly necessitates the worker's reading and writing skills from the potential applicants- the senior high school learners.

These skills needed in tourism are manifested in the human resources skills in which the government needs to invest via education. The dynamic effect of tourism to local economic opportunity includes the investment in human resource skills (Ashley et.al., 2007). These human resource skills can be converted from tourism to other areas of development. But the teaching-learning process of communication skills and knowledge would not be holistic without attitude in it. For students to effectively attain academic and personal success and fulfillment, it is vital for teachers to continuously educate themselves of the diversities and ethnicities of students. This cultural knowledge and cross-cultural communication skills needed by the teachers serve as their important guideline to create a global society (Pratt-Johnson, 2006). In this light, instructional materials for reading and writing can be an avenue for students to be well prepared of the career ahead of them.

IMs that are localized pave way in strengthening the youth and the local people in the preservation of rural culture and heritage. People will be inspired to preserve their culture and heritage when they will understand that their culture and heritage are the sources of their prosperity (Varquerizo, 2013). Thus, this study.

\section{Literature Review}

\subsection{Contextualizing the Reading and Writing Instruction}

Ayson (2016) used a culture-based teaching method in contextualizing a core subject like Reading and Writing in SHS. Contextualization is where content knowledge can be readily understood by the students. Contextualizing content standards can be done using the cultural treasures or assets, namely, cultural heritage, icons, resources and expressions. First, cultural heritage refers to any natural, human-made, intangible and movable in the locality. Second, cultural icons refer to person, object, place or event. Third, cultural resources refer to the creative cultural occupation, community cultural organization, spaces and facilities, festival and events, or creative cultural industries. Lastly, cultural expressions refer to values, norms, knowledge, beliefs, practices, or language unique to the local community. These are instrumental in designing IMs for language learners.

When designing IMs that help students in understanding their culture, it is helpful to consider the cultural treasures or assets of the locality. IMs contextualization of content standards for reading and writing is an instructional intervention to help both the teachers and the language learners to have a grasp of their cultural treasures or assets.

The NCTE (2016) provides guidelines of materials in an English Language Arts Program which can be generalized into two: its connection to the educational objectives, and its capacity to address the needs of the students for whom the materials are intended. The conventional notion of instructional materials as textbooks and workbooks has basically engaged graphic novels, informational text, websites, and technology. IMs are now inclusive to both print and digital materials for learning. 
Warren (2012) suggested that IMs be gauged in its efficiency by considering the areas of emphasis, unity, coherence, repetition, appropriate vocabulary, audience appropriateness, format, and reinforced by the caliber of questions the teacher uses when establishing connection between the reading text and students. Audience appropriateness serve as the focal point in this endeavor. Similar to the previous discussions, learners are taken a weighed regard in the instructional process.

The guidelines, principles and designs that were previously mentioned create an eclectic view of the module that this study aims to achieve. The implementation phase is an extended IMs development phase in such a way that whatever adjustments there may be in the classroom setting, the teacher would always consider the welfare of the student's learning condition. There are varied perspectives that a Reading and Writing Skills teacher consider when implementing instructional tools.

\subsection{Developing the Reading and Writing Skills}

Langer and Flihan (n.d.) discuss the development of reading and writing of the students in the constructivist perspective. Since learners are regarded as an active problem-solvers, they are bound to think and understand abstract information through their background knowledge, text, and context. The theory on constructivism explains that whether students read or write, their life experiences as well as how they relate to the subject or topic affect their reading and writing functions.

In relation to the constructivist theory of needs analysis, a Reading and Writing teacher needs to identify the target tasks for the group of learners. Then, the teacher secures the samples of target discourse of those tasks. Task-related written discourse should also be considered and be varied cross-culturally, and in the degree of presupposed knowledge, or information density. Analyses may also need to be conducted on written texts- basing on the tasks listed in the curriculum guide as to the academic and professional correspondences.

While in the teaching of reading and writing in the senior high school, it focuses on the capability of students to critique a written text. This demands student's capability to have critical reading skills which is not so much given emphasis on the books reviewed. As synthesized on the course's curriculum guide, the critical reading skill serves as a foundation or springboard of the reader to be able to write academic writing outputs, namely, book review or article critique, literature review, research report, project proposal, and position paper.

After having written exercises in the academic context, professional correspondence is the next written output that the students need to practice. Professional correspondences included in the Reading and Writing course are: resume, application for college admission, application for employment, and various forms of office correspondence. Writing skill is a more directed and purposive target task in the senior high school wherein critical reading skill plays a crucial role.

Critical reading as reflected in the SHS curriculum guide provides reading activities as ways of thinking and reasoning. Interaction which is from the reader to the text, is a nature of discourse. Thinking in critical reading pertains to the capability of the student to identify claims explicitly or implicitly made in a written text, such as claims of fact, policy, or value. Reasoning in critical reading refers to the student's skill of identifying the context in which a text was developed, whether hypertext or intertext.

In the real setting, students are having limited reading resources. Those that prepare them for work, known as the "content area reading" resources (Ulusoy, 2011). One important barrier to acquiring reading skills is the lack of reading materials. It was claimed in this study that when students understand the advantages of reading in their content areas, they will feel better prepared for work. While acquiring the skills in reading and writing, they also see themselves as content specialists. In the teaching of literacy, educators must move beyond acquiring the skills enlisted in the CG and address the specific texts, literacies, literacy strategies and instructional methods in discipline-appropriate ways.

The schema theory of Ausubel as mentioned in the report of Anderson, R. et.al. (1977) stresses the help of schemata or familiar situations in a reading text through learning an unfamiliar task. This "ideational scaffolding" enables the reader to hone his/her skill in the process while retaining the textual information in mind. Abstract information is introduced from a contextualized material. The localized teaching materials in the course will then help the readers make sense of what one reads. 
Reading defines the student's academic progress. It is a further disadvantage for a senior high school student who has issues on comprehension or cannot understand what has read. What purpose will it have for well-crafted curriculum if the student does not make meaning on what is given to him? Reading is a skill that is necessary for him to participate in the 21 st century workforce.

Olson (2011) in his article confirms the opportunity of using the language that brings one into a new way of using the mind. When adapted to a variety of social and personal functions, written discourse can be a meaning-driven task when dealing with new set of information.

Canine (2004), recognized the "Mathew Effect" by Stanovich which speaks of motivation in reading. It is a biblical rooted phrase that says the richer a reader gets the more $\mathrm{s} /$ he reads. The previous readings establish connection from one reading to another which reinforces the habit of reading. In its opposite, students who find it hard to comprehend in reading the text might withdraw from reading, thus, the opportunity to grow their skill will be taken away from the poor reader. This seems to be an outcry, especially to schools or students whose environment cannot practically provide them with these learning opportunity. Instructional materials are a good start. At the same time, crucial point for students to be hooked into the reading material which they could establish schema. Teachers as well are instrumental in making IMs to motivate, and not to stifle the reading skill of students.

\subsection{Theoretical-Conceptual Background}

This study is anchored on Culatta's (2016) "Personalized Learning Initiative", a model relative to the development of a culture-based IM. Culatta (2016) proposed that when using technology in the classroom, it must not be that the teacher simply lifts the print and use technology as a medium, for example, in reading. It does not encourage innovative learning after all. Learning initiative happens when the students utilize technology reinforcing their problem-solving skills and experiences. This is known as the Personalized Learning Initiative. Technology and experience help the students to learn the skills. However, learning is not the end point. The building up of experiences could give students an opportunity for identity of self through the environment. Culture is a factor for one's learning.

This model of learning regards social media, computer gaming, and the like, the effective "large-scale distributed learning environments". The cycle of information becomes a large-scale negotiation of meaning and growth when learners are immersed in the digital environment. Students become active participants in the learning process. It is then impossible in the learning process to have an autopsy data, a learning that comes after it's too late. Technology is then the key to address knowledge gap for learners of this digital age.

Experiences provide basic foundation for the students to learn the literacy skills. These may have or be taken from the environment, a culture-rich environment, and are instrumental in teaching the literacy skills. Teachers make learning a relevant and meaningful undertaking when the tasks involved in the teaching of literacy skills are rooted on student's experiences.

Highlighting the student's learning is the transfer of learning stage. This is when they are provided with tasks that would enhance their learning of the skills. In this stage, learners would find these tasks meaningful when they see a relevance of this task to their future work field. Learning becomes a rewarding task.

Technology is used to accelerate innovation in education, corporate, and government settings. This calls a need for expanding internet connectivity to schools across the country, promoting personalized learning, and developing a national ed-tech plan (Culatta, 2016).

A theory relative to the model of Culatta is the Functional Context Theory by Sticht (2000). This theory requires adult learners to be fully equipped with their own culture, having prior and relative knowledge for a meaningful learning as possible. Culture can be embedded in a reading text for instruction. In this manner, students are given input of their own culture, and at the same time, culture is put into the context of learning a specific language skill.

Similarly, constructivism claims that people make use of their past experiences in constructing understanding of new concepts. This means that an effective instruction involves transfer of learning through previous or prior knowledge. This foundation of learning has substantially equated the context in the functional context theory and the symbolic acts of 
purposive communication. David Ausubel as quoted in Rusbult's (2007) journal elaborated the same concept in his theory called Meaningful Reception Learning which states that "the most important single factor influencing learning is what the learner already knows."

In developing a localized and tourism-focused IMs, the Reading and Writing course is the core curriculum subject selected for this study. Reading and Writing Skills course in senior high school is one of the three English subjects in SHS. The essence of this course is on honing the students' capability to write a written output that is interactive of the readers, their future clients in the performance of their tasks. This course, can then be deemed in line with the constructivist's theory, specifically on the use of language to the target participants in the communicative interaction. The model of Canale and Swain in 1980 further elaborates the theory and that includes four components, namely, grammatical competence, sociolinguistic competence, discourse competence and strategic competence.

The localized instructional materials expected of this study respond to the DepEd's mission which is "to protect and promote the right of every Filipino to quality, equitable, culture-based, and complete basic education". Providing a motivating environment to students is tantamount to giving them opportunities to learn in a familiar context as possible. The community, and other stakeholders are actively engaged and currently share responsibility for developing life-long learners by helping in the learner's OJT program in the SHS.

The Enhanced Basic Education Act of 2013 (RA 10533) also mandates DepEd "to enable and allow schools to localize, indigenize and enhance instruction based on their respective educational and social contexts". These require students and teachers to acquire understanding of the local context.

The teaching and learning tools are used to shape and determine what students learn and how they learn. In this case, tools that are taken from the social and cultural forces are required in order to develop the cognitive capacities to their full potential, including language and symbolic reasoning (Perin, 2011). This local-based instructional approach is known as Contextualized Teaching and Learning or CTL.

Theories behind CTL include motivational, problem-centered, social-learning, and brain research theories. These theories coincide with constructivism in the teaching of reading and writing which is the focal point of this study. The use of contextualized learning material aids students to be motivated, and socially learned. In the constructivist's point of view, background knowledge helps the learner to interact with the read text and thus be able to create a discourse in the context of the reading and writing course (Anderson, Spiro \& Montague, 1977; Halliday, 1976; Vygotsky, 1978, 1986). The support of the stakeholder in the learning process intensifies the learning experience aside from the support of the family, school and community.

Motivation theory relates to constructivism. It drives learners into a meaningful task since the "so what" question has been satisfied. Predmore (2005) asserts that once the students see the real-world relevance of what they are learning, they become more interested and motivated. The teacher's goal is to provide concrete context not far from the student's grasp.

On the other hand, "learning for its own sake" is de-emphasized in the problem-centered learning theory. This theory states that the learners would develop creative solutions with the skills and information they gained given the real-world problems. The real-world problem refers to the target task they might realistically come across in the performance of their job.

The convergence of a real-life application in the process of learning a new knowledge is an activity explained in the neuroscience, another theory supporting constructivism in learning the reading and writing competencies. Contextual teaching and learning stimulates the brain and enables the learner to create meaning by linking experience and sensory stimuli to a new knowledge (DeLott Baker, E., et.al., 2009).

In the process of instructional designing for the Reading and Writing Skills, the instructional-design theory of Reigeluth (2016) is followed. Specifically, it enumerates the assessment-needs analysis-implementation-IM development scheme. It gives an explicit guidance expressed in an instructional-design model. The designing of instructional materials would be easier since the target aspect of development (cognitive, emotional, social, physical and spiritual) is identified in its model. 
In the context of this study, the senior high school students to take the core subject Reading and Writing are known as the "crucial sources" of this analysis. Sources could mean published or unpublished literature. Another source that this study utilizes is the reading and writing competencies from the curriculum guide. It is used to identify the students' current proficiency level in terms of their reading and writing skills. Long indicated that the reliability and validity of a needs analysis (NA) can be improved when using multiple sources of information through triangulation method and sources.

While the theory of instructional-design elaborates varied possible process of how to go about the designing of instructional materials, the Philippine Tourism Goal suggests a value-rooted content on the IMs.

The Philippine tourism goal shared by the Philippine National Tourism Development Plan is taken into consideration. The promotion of tourism must be accompanied by sustainable development goals. For what purpose will it serve the people if nature is diminished in the process? Tourism goals are accompanied by tourism values geared towards honing the learners to become "environmentally and socially responsible". So, in identifying the target tasks, this goal is also importantly taken into account. The teaching of reading and writing skills for tourism-focused curriculum is grounded on this goal.

This tourism goal is reinforced with the 2018 target plan which is "Purposive communication". Recently, this becomes the focal point in tourism's training of teachers in the Higher Education Institution for the HEI students and for the Grade 12 students of senior high school. It brings out man's capacity for a varied combination of symbolic acts, or simply put, the use of language skills that must involve organizational communication (for the management implications), the social sciences (for the developmental implications), critical theory (for the non-verbal implications of the words), accountancy (for the significance of the financial data to be reported), philosophy (for the ethical implications), and other disciplines (Cruz, 2014).

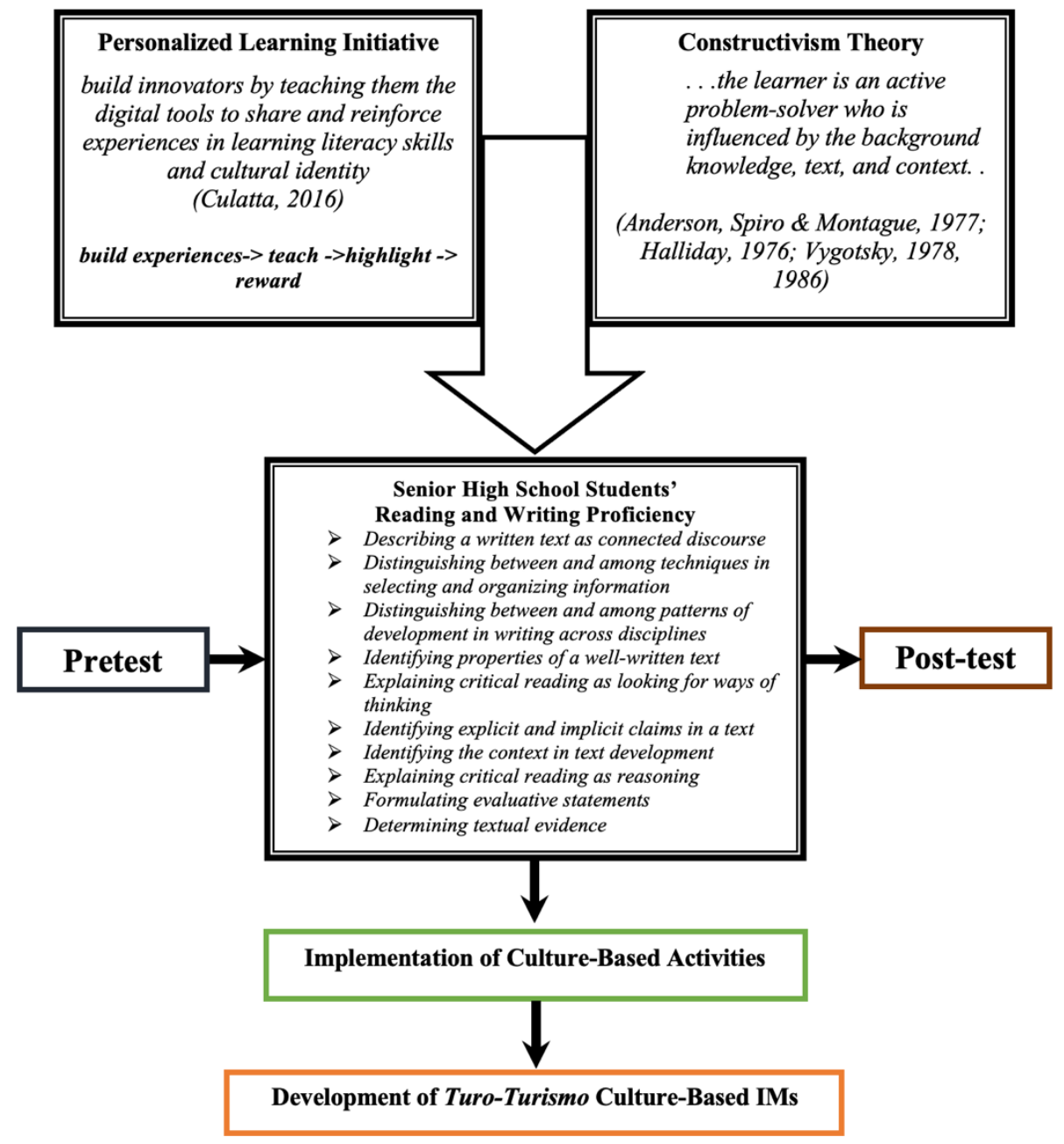

Fig. 1. Theoretical Conceptual Framework of the Study 


\section{Statement of the Problem}

This study aims to assess the development and utilization of the culture-based learning activities to the senior high school students' reading and writing. Specifically, (1) determine the pre-post reading and writing proficiency level of students based on ELC Proficiency Scale in terms of the ten Reading and Writing Skills Course Competencies; (2) identify the significant difference of the pre and post Reading and Writing proficiency levels; (3) calculate the significant mean gain difference of the pre and post Reading and Writing proficiency levels; (4) illustrate the implementation of culture-based activities; and, (5) develop the Turo-turismo-based instructional materials.

\section{Research Methodology}

This study employed a mixed method of quantitative and qualitative designs. Quantitatively, a quasi-experimental one shot design was conducted to find out the gain of the pre and post-test after an educational intervention which is the Turo-turismo Culture-based IMs. This design requires a pretest and post-test to the tested group.

The pretest was conducted to identify which competency needs instructional focus. This paved way to the development of a contextualized IMs.

Qualitatively, culture-based activities were implemented to enrich the learned competencies of the course. The students' output is gauged using the ELC Framework. The feedback of students are taken after finishing each culture-based activities.

Convenience sampling was used to select the eighty-eight students in Lourdes National High School (LNHS) which is located in Lourdes, Panglao, Bohol. This school nationally pilots the Turo-turismo Program specifically in senior high school which started this school year 2016-2017. The province of Bohol chiefly chose Panglao to implement this program first considering the significant amount of tourists visiting the town as compared to other towns in Bohol. With the united efforts of DepEd, Coalitions for Change in Education partnership of The Asia Foundation-Australian Embassy in the Philippines, Bohol Association of Hotels Resorts and Restaurants (BAHRR), the Provincial Government of Bohol and LGU Panglao, a tourism facility or a "mini-hotel" is built within the campus of LNHS solely for this tourism program.

The effectiveness of these IMs were tested using the validated post-test to check whether or not there is a significant change or growth with the use of the intervention (IMs). Learner's feedback was manifested in their reflection write up.

The students' answers on the pre and post-tests were given a descriptive statistical analyses through simple mean and standard deviation. In identifying the students' proficiency level, the mean value is assigned a particular point according to the ELC Proficiency Scale. Where a mean score of 4.00 is equivalent to launch which is the highest level in the Reading and Writing Scale, 3.5 to 3.9 is a high advanced proficiency level, 3.0 to 3.4 is on a low advanced level, 2.5 to 2.9 indicates a high intermediate proficiency level, 2.0 to 2.4 means a low intermediate proficiency level, and a mean score of 1.0 to 1.9 is a foundations level of proficiency.

The ELC Proficiency Scale was instrumental in the study since this deals with gauging the proficiency level of a language learner, particularly including the skills reading and writing, with culture and its corresponding indicator. Through this scale, the mean score was given a description relative to the students' responses which accordingly tells to which proficiency level the students' response or chosen test option belongs. Significant mean gain and significant mean gain difference in the pretest and post-test were also computed using the paired t-test. The qualitative analysis was on the selection of cultural activities for the module.

\section{Results}

The pre-post reading and writing proficiency level of students (based on the ELC Proficiency Scale) in the following competencies are:

1.1 In describing a written text as connected discourse, the students answered from intermediate (high) level in the pretest to the advanced (high) level in the post-test;

1.2 In distinguishing between and among techniques in selecting and organizing information, the students answered from advanced (low) level in the pretest to the advanced (high) in the post-test; 
1.3 In distinguishing between and among patterns of development in writing across disciplines, the students' proficiency level was advanced (low) in the pretest while their proficiency level in the posttest was advanced (high);

1.4 In identifying the properties of a well-written text, the student's proficiency level was intermediate (high) in the pretest and advanced (high) in the post-test;

1.5 In explaining critical reading as looking for ways of thinking, the students' proficiency level in the pretest was intermediate (high) while advanced (high) in the post-test;

1.6 In identifying explicit and implicit claims in a text, the proficiency level in the pretest was an intermediate (high) while in the post-test proficiency level was an advanced (high);

1.7 In identifying the context in text development, the proficiency level in the pretest was intermediate (high) while in the post-test proficiency level was an advanced (high);

1.8 In explaining critical reading as reasoning, the pretest proficiency level was intermediate (high) while the post-test proficiency level was an advanced (high);

1.9 In formulating evaluative statements, the pretest proficiency level was intermediate (low) while the post-test proficiency level was an advanced (high);

1.10In determining textual evidence, the pretest proficiency level was intermediate (low) while the posttest proficiency level was an advanced (high).

There a significant mean gain of the pre and post Reading and Writing proficiency levels. The highest mean difference obtained is the competency\#9 while the competency\#2 has the least mean difference.

There is a significant mean gain difference of the pre and post Reading and Writing proficiency levels. The student's proficiency level from the pretest and post-test has increased, from intermediate (high) level to advanced (high) level.

The implementation of culture-based instructional materials incorporated in the module have awakened the student's personal, social, cultural and intellectual aspects. The reflections of the students underscores the development of these aspects and is heightened when they realize the relevance of these tasks to their future work or in their personal lives.

The instructional materials developed in the module are those that include reading articles related to social and environmental issues.

\section{Discussion}

The data implicitly showed that in the pretest, students found it challenging to achieve critical reading. Reading texts with contents related to life experiences would help adult learners to think of strategic ways to solve an issue. Imel (2000) calls this a "functional context". It is when readers are driven to explain circumstances relevant to the text read and are motivated to think based on their experience. Experience, as a functional context, is a resource and a stimulus for learning the skill.

If the concept of "purposive communication" is to be taken into account in learning the skill (Cruz, 2014), then the activity on product or item designing could help the learners transfer their learning. Purposive communication would also rely heavily on the relevance of the task to the potential work that the student plans to have in the future. It asserts that learning is engaging students to other disciplines. Skill, in its language sense, cannot be taught in an empty vessel. The medium is through a meaningful yet worthwhile task. Students might as well be motivated to search for relevant information that should help them arrive at an eclectic idea through hyper and intertext.

In the post test data results, it was clearly shown that the learning of the target competencies were achieved at a higher level. Consequently, the instructional intervention proved an effective tool in improving the proficiency levels of the students in every competency. The highest mean difference obtained is competency $\# 9$ with a mean of $1.32(\mathrm{sd}=0.43)$. This means that there is a greater improvement of the student's proficiency level in this competency based on the pretest and post-test mean difference. While it does not guarantee that the activity incorporated in the instructional material is the most effective, it is emphasized that the growth of learning may have caused by several factors as the activities incorporated, the instructional strategies used, the involvement of technology or any other stimulating tool for learning.

As to quantifying whether or not there was a significant mean gain difference of the pretest and post-test of the Reading and Writing Proficiency levels of students before and after introducing the Turo-Turismo Culture-Based IMs, the following table capsulized the results of the paired T-test scores in the pretest and post-test Reading and Writing proficiency 
levels.

Table 1. The Significant Mean Gain Difference of the Pre \& Post Reading and Writing Proficiency Levels

\begin{tabular}{lllllll}
\hline Test & N & Mean & SD & Description & t-value & p-value \\
\hline Post & 88 & 3.777 & 0.118 & Advanced (high) & 41.5 & 0 \\
Pre & 88 & 2.677 & 0.294 & Intermediate (high) & & \\
Difference & 88 & 1.1 & 0.248 & & & \\
\hline
\end{tabular}

With the t-value of 41.5 , and a 0 p-value, the pretest mean is 3.8 while the post-test mean is a 2.7 which yields a significant difference of $1.1(\mathrm{sd}=0.25)$. This indicates that there is a significant mean gain difference between the pre and post-tests. It means that the student's proficiency level from the pretest and post-test has increased, from intermediate (high) level to advanced (high) level.

It can be inferred from the results of the significant mean gain that the instructional intervention implemented during the instruction were effective in improving the proficiency level of the students. The pretest posed an instrumental tool in establishing the instructional decisions. The results affirmed the research finding of Yilmaz and Kiraz (2009) and Richards (2010) regarding the learner analysis as the first step in instructional designing. The theory in which this study was based on which is the Instructional-design theory of Reigeluth (2016) served as the pillar to this research, especially in developing an instructional material.

\section{Conclusion}

The needs assessment helped generate an effective instructional tool in designing activities for each competency. Furthermore, the culture-based activities embedded in the learning tasks with the contextualized reading texts improved students' proficiency level in Reading and Writing Skills. These motivated students to perform the task, most especially when they realize that having these competencies puts them at an advantage level and help them in their future work life. Finally, students found learning a meaningful and purposive task when they feel a sense of involvement in helping their community survive by taking care of their natural resources. Thus, the developed IMs in this research proved an effective tool in the teaching and learning of Reading and Writing Skills.

\section{Recommendation}

In crafting IMs specially one which is contextualized and culture-based for Reading and Writing Skills, purposive writing needs to be sought in every writing task. Students may be encouraged to write an expression of meaning after being exposed to a text type. Having them exposed in various text types would also allow them to digest these reading materials through writing activities that are suitable to their purpose of writing. Reading assignments could be a way to encourage learners to be independent readers. A stimulating writing activity can be prompted from a relevant reading activity. Culture is a useful and engaging tool for a reading task.

The tasks included in the instructional materials may enable students to read texts and incorporate strategies to develop thinking in critical reading. The thinking aloud strategy is also an explicit way of guiding students to exercise this skill. Reading texts with contents related to life experiences would also help adult learners to think of strategic ways to solve an issue.

Profiling of students can also be a great way to assess students' forte, likes, inclinations, and experiences that make them unique individuals. Experience, as a functional context, is a resource and a stimulus for learning the skill.

The contextualization of reading materials can help students to increase their basic skill mastery and transfer of knowledge. The culture-based activities need to be incorporated in the classroom instruction. Culture is an encompassing medium of developing not just the skills but the personal aspects of the learner. Teachers are encouraged to utilize the module and the culture-based activities included in the module as a full-implementation of this in a Reading and Writing Skills class.

For students as readers, they can be sensitive to the supporting statements expressed in the text to bring out the writer's stand on the topic. When it comes to the availability of reading texts, environmental issues are a good source of cultivating a rich and meaningful discussion upon learning the skill. For them to reinforce their writing skills, writing 
springs from a moment of expression and inspiration. The medium of writing might be a source of inspiration (Genlott \& Gronlund, 2013). Students can make use of the digital or the millennial way of learning. This might as well be a starting point where the learning of skill would be in the medium where students are inspired to express. Teachers also need to guide students on the values that a responsible media user must have.

\section{Acknowledgements}

The researcher acknowledges the people behind the completion of this research and module/book works: Dr. Vinchita G. Quinto, the CNU adviser and pen-pusher, who has veered the once-a-plain-iplan compilation into a functional module; the CNU panel members chaired by Dr. Ethel L. Abao who generously poured out ideas for the improvement of this work; Dr. Carmel Vip C. Derasin, who triggered the researcher's passion to reach the finish line; Dr. Remedios C. Bacus who has always been willing to offer her time and expertise for the enrichment of this work; Dr. Cristie Ann J. Delfin, who manifested a value-added work that has motivated the researcher not to settle for mediocrity; to Dr. Obaob who helped in the statistical computation of data; Ma'am Josephine Cabarrus, the head of the Bohol Tourism Office; Mr. Jemboy Valloso, the eye-opener when in work immersion, who also helped in the layout of the module; Mr. Niel John S. Bulacan for the further illustration of the module turned into a book and for the inspiration; Dr. Joey D. Jabonete for the guidance given for this publication to happen; Dr. Elena Hopkins, Dr. Sheila Niones, and Dr. Maritoni Baldespiñosa, the ELT Buddies, the circle of inspiration since the CNU life-story started; Mr. Arturo B. Arboladura, the former BAHRR president, whose wisdom was gratifyingly overwhelming and that inspired the researcher to create a module; Dr. Vitaliano and Dr. Beatriz C. Luga, the Doctors in Education whose dedication and service to DepEd served as my personal motivation to continue, this writer is humbly indebted!

\section{References}

Abeberese, A.B. et. al. (2013). Improving reading skills by encouraging children to read in school: A randomized evaluation of the Sa Aklat Sisikat reading program in the Philippines. Retreived January 2, 2017, from http://www.nber.org/papers/w17185

Ashraff, M. (2015). Tourism? Well first, put your money where your mouth is.

(Online news). Retrieved August 4, 2017, from http://www.thecitizen.in/index.php/NewsDetail/index/4/4759/Tourism-Well-First-Put-YourMoney-Where-Your-Mouth-Is

Anderson, R. C., Spiro, R. J. \& Montague, W. E. (1977). Schooling and the acquisition of knowledge. Hillsdale, NJ: Erlbaum

Anderson, R.C., et.al. (1977) Schemata as scaffolding for the representation of information in connected discourse. University of Illinois, Urbana, Illinois

Ashley, C. et.al (2007). The role of the tourism sector in expanding economic opportunity. Corporate social responsibility initiative report no.23. Cambridge, MA: Kennedy School of Government, Harvard University

Ayson, J.C. (October, 2016). Culture-based lesson integration. Seminar-workshop on culture-based education, 2016. National Educators Academy of the Philippines. Department of Education, Philippines

Bolarinwa, O.A. (2015). Principles and methods of validity and reliability testing of questionnaires used in social and health science researches. http://www.npmj.org/

Burden, P.R. \& Byrd, D.M. (2010) Methods for effective teaching. Meeting the needs of all students (5th Edition). USA: Pearson

Carnine, D.W., et.al. (2004) Direct instruction reading. USA: Pearson

Carswell, J. (February, 2009). Theories of Instructional Design http://www.slideshare.net/jcarswell/theories-of-instructional-design

Christensen, T. (April, 2008) The role of theory in instructional design: Some views of an ID practitioner. International Society of Performance improvement, Vol. 47, No. 4

Coyne, M.D., et.al. (2007) Effective teaching strategies that accommodate diverse learners (3rd Edition) New Jersey: Pearson Education, Inc.

Cruz, I. (September, 2014). Purposive communication. The Philippine Star. Retrieved September 6, 2017, from http://www.philstar.com/campus/education/2014/09/04/1365213/purposive-communication

Culatta, R. (2015) Functional Context. Retrieved August 2, 2017, from http://www.instructionaldesign.org/theories/functional-context.html

Dadufalza, C.D. (1992). Reading into writing 1. English for academic purposes: A handbook-workbook for college freshman English. Philippines: Bookmark, Inc.

Dadufalza, C.D. (1996). Reading into writing 2. English for academic and professional purposes: A handbook-workbook-reader for critical reading and writing in expository discourse. Makati City, Philippines: Bookmark, Inc.

David, C. \& Albert, J.R. (March 2012). Philippine Institute for Development Studies (PIDS). Primary Education: Barriers to Entry and Bottlenecks to Completion. Discussion Paper Series No. 2012-07. Retrieved August 27, 2017, from http://dirp3.pids.gov.ph/ris/dps/pidsdps1207.pdf

Dayabil et. al. (2016). Critical reading and writing for senior high school. Quezon City, Metro Manila: Lorimar Publishing, Inc.

DeLott Baker, E., et.al. (2009) Contextualized teaching \& learning: A faculty primer. A review of literature and faculty practices with implications for California community college practitioners. The academic senate for California community colleges.

Department of Tourism (2016). Statistics, Economic Analysis and Information Management Division (SEAIMD)- People and Religion. Retrieved October 9, 2017, from tourism.gov.ph

Education for All 2015 National Review Report: Philippines. Retrieved from August 7, 2017, from efa2015review@unesco.org

Filipino Culture 
Filipino foods

https://www.univie.ac.at/ksa/apsis/aufi/ethno/paradox.htm

https://scontent-sea1-1.cdninstagram.com/

https://images.summitmedia-digital.com/yummyph/images/2017/11/26/puto-maya.jpg

https://images.locanto.ph/Original-lechon-tasty-crunchy/vap_1871054181.jpg

https://tinyurl.com/yxcnz6f6

Flavin, B. (March, 2016). 8 Human resources job skills employers want most. Retrieved

August 5, 2017, from http://www.rasmussen.edu/degrees/business/blog/humanresources-job-skills-employers-want-to-see/

Freiberg, H.J. \& Driscoll, A. (2000) Universal teaching strategies (3rd Ed). USA: Allyn and Bacon

Genlott, A.A. \& Gronlund, A. (March, 2013) Improving literacy skills through learning readng by writing: The iWTR method presented and tested. Orebro University, Orebro, Sweden

Ghufron, M.A., et.al. (2016) A Model of Research Paper Writing Instructional Materials

for Academic Writing Course: Needs and Documents Analysis and Model Design. Semarang State University, Indonesia

Gill, V. (2009) The eleven commandments of good teaching (3rd Ed.) USA: Corwin

Goatly, A. (2000) Critical reading and writing: An introductory coursebook. Canada: Routledge

Guidelines for National History Day Interviews. Retrieved http://www.dceverest.org/srhigh/socialstudies/histday/Process/oral_histroy_process.htm

Halliday, M. A. K. (1976). Learning how to mean. NY: Elsevier N. Holland

Hosking, R. (March 25, 2014). Executive Secretary Magazine. Why good writing skills are important in today's workplace and tips for developing them. Retrieved August 8, 2017, from http://executivesecretary.com/why-goodwriting-skills-are-important-in-todays-workplace-and-tips-for-developing-them/

Hunter, M. (1976) The Madeline Hunter Model of mastery learning. Retrieved September 4, 2017, from http://www.onetohio.org/library/Documents/Dr\%20Madeline\%20Hunter\%20Arti cle1.pdf

Imel, S. (2000) Contextual learning in adult education. Clearinghouse on adult, career, and vocational education. College of Education. The Ohio State University.

Kalchik, S. \& Oertle, K.M. (September 2010). The theory and application of contextualized teaching and learning in relation to programs of study and career pathways. College of Education. University of Illinois at Urbana-Champaign

Kurland, D. J. (2000) Critical reading v. critical thinking. Retrieved August 21, 2017, from http://www.criticalreading.com/critical_reading_thinking.htm

Langer, J.A. \& Flihan, S. (n.d.) Writing and reading relationships: Constructive tasks. Retrieved August 10, 2017, from http://www.albany.edu/cela/publication/article/writeread.htm

Long, M.H. (2013). The encyclopedia of applied linguistics. Needs analysis. Blackwell Publishing Ltd.

Luz, J.M. (June, 2007). iReport- Literature and literacy. A nation of non-readers. Retrieved August 10, 2017, from http://pcij.org/stories/a-nation-of-nonreaders/

Martinez, D.A. \& Cardona, F.J. (2012). Describing two teachers' instructional design for language teaching and its relation to Colombian standards. Universidad Tecnologica. Colombia.

NCTE National Council of Teachers of English (2016). Guidelines for selection of materials in English language arts programs. Retrieved August 10, 2017, from http://www.ncte.org/positions/statements/material-selection-ela

Okabe, M. (August, 2013). Where does Philippine education go? The "K to 12" program and reform of Philippine basic education. Institute of Developing Economies (IDE) Discussion Paper No. 425. Retrieved August 7 , 2017, from https://ir.ide.go.jp/dspace/bitstream/2344/1267/3/ARRIDE_Discussion_No.425_okabe.pdf

Olson, D.R. (Dec, 2011). A theory of reading/writing: from literacy toliterature. OISE, University of Toronto, Canada.

Pappas, C. (December, 2013). Instructional design models and theories journey. Retrieved August 5, 2017, from https://elearningindustry.com/instructional-design-models-and-theories

Perin, D. (2011). Facilitating student learning through contextualization. Teachers College, Columbia University. New York

Philippine education for all 2015 review report. Retrieved July 29, 2017, from http://unesdoc.unesco.org/images/0023/002303/230331e.pdf

Polit, D.F. (2007). Focus on research methods: Is the CVI an acceptable indicator of content validity? Appraisal and recommendations. Research in Nursing and Health. Griffith University School of Nursing, Gold Coast, Australia: Wiley Periodicals, Inc

Pratt-Johnson, Y. (2006). Communicating cross-culturally: What teachers should know. The Internet TESL Journal, Vol. XII, No. 2, February 2006. Retrieved August 10, 2017, from http://iteslj.org/Articles/Pratt-Johnson-CrossCultural.html

Predmore, S. R. (2005). Putting it into context. Techniques. Retrieved October 9, 2017, from http://www.acteonline.org

Reigeluth, C. (2016) Instructional-design theories and models: The learner-centered paradigm of education (Vol. IV). New York: Routledge

Reigeluth, C. (September, 2011). Instructional theory and technology for the new paradigm of education. RED, Revista de Educacion a Distancia. No. 32.

Reigeluth, C. (n.d.) What is nstructional-Design Theory and how is it changing? Indiana University. Retrieved July 29, 2017, from https://www.ou.nl/docs/faculteiten/ow/o21411_reigeluth-snelbecker.pdf

Richards, J.C. (2006). Communicative language teaching today. USA: Cambridge University Press

Richards, J.C. (2010). Curriculum approaches in language teaching: Forward, Central, and Backward Design. RELC Journal, Vol.22, Issue 1. University of Sydney, Australia.

Rivers, W. (2000). Interactive language teaching. Cambridge, UK: Cambridge University Press

Rusbult, C. (2007) Teaching Strategies for Effective Instruction. Retrieved September 4, 2017, from http://www.asa3.org/ASA/education/teach/active.htm\#

San Juan, E. Jr. (1999) The Paradox of Multiculturalism: Ethnicity and Identity in the Philippines https://www.univie.ac.at/ksa/apsis/aufi/ethno/paradox.htm 
Selangan (2015) The reading profile of children in the Philippines. Retrieved August

2017, from http://www.edutopia.org/discussion/reading-profile-children- philippines

Stepp-Greany, J. (2003) Designing instructional technology for language learning.

Vol. 7, Issue 4. Florida State University

Sticht, T. (2000). Functional Context Education: Making Learning Relevant. Retreived

February 21, 2018, from http://www.instructionaldesign.org/theories/index.html

Syatriana, E., et.al. (2013) A model of creating instructional materials based on the school curriculum for Indonesian secondary schools. State University of Makassar, Indonesia

Tiongson, M.T.A. \& Rodriguez, M.R.C. (2016). Reading and writing skills (1 ${ }^{\text {st }}$ Edition). Philippines: Rex Book Store, Inc.

Ulusoy, M. (2011). Content area reading and writing: Practices and beliefs. Gazi University, Turkey

Vaquerizo, F.L. (2013). Rural tourism development in Nepal. Bachelor's Thesis. Degree Programme in Tourism. Tampere University of Applied Sciences

Vinuya, R.V. \& Buri, S.C. (1997). College reading and writing: Textbook with workbook. Philippines: Grandwater Publications and Research Corporation Vygotsky, L. S. (1978). Mind in society. Cambridge MA: Harvard University Press.

Waltz C. F. \& Bausell, R.B. (1983) Nursing research: Design, statistics and computer analysis. 2nd Ed. Philadelphia: FA Davis Company

Warren, J. (November, 2012) Criteria for selecting instructional materials. Retrieved October, 2017 from http://www.slideshare.net/jhackwarren/criteria-for-selecting-instructional-materials

WEM- Workplace Education Manitoba (2016). The nine essential skills. 1000 Waverley St, Winnipeg, MB R3T 0Y4, Canada. Retrieved August, 2017, from http://www.wem.mb.ca/the_9_essential_skills.aspx

Yaghmale F. (2003). Content validity and its estimation. Journal of Medical Education. Spring, 2003 Vol. 3, No. 1. Nursing and Midwifery School, Shahid Beheshti University of Medical Sciences and Health Services

Yilmaz, A. \& Kiraz, E. (2009). Instructional design taking roots from globalization toward institutionalization. World Conference on Educational Sciences. Science Direct, Procedia Social and Behavioral Sciences

\section{Appendix A. Module Sampler of the Developed and Implemented Turo-Turismo Culture-Based IMs}

\section{A.1. Module Cover}

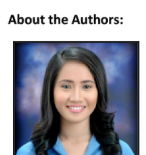

Bohol Division, Lourdes National High School of Panglan Is sland which is is national pioneering school implementer of the Turo-Turismo Program. She finished both Teaching at Cebu Normal University: her Bachelor of in English at Holy Name University, Tagbilaran City, Bohol. The contextualized output from her Masters and Doctorate researches have substantially

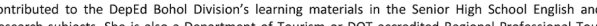
training in teaching Japanese language to the DepEd High School students. She is currently a research Whacher, a national trainer for the school-based research, and a foreign language traning speaker for

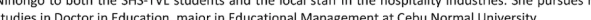

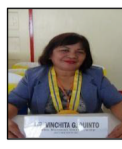

TA G. QUINTO, EdD earned her Doctor of Education, major in English language Teaching at Cebu Normal University. She is a full-fledged professor and currently the chair in the School of the Arts Extension Services in the College Arts and Sciences and the Assistant Director of the Extension and Community
Development at CNU. She is a resource speaker of the educational topics such a the Senior High School Curriculum, the Syllabus Design Training, the Philippine Professional It andard for Teachers (PPST), and the Teaching Stratageies. She has
served as a trainer of the English Summer Camp at Aletheia University, Taipei City, Taiwan; the Purposive Communication (New General Education Curriculum); and, the K-12 Curriculum

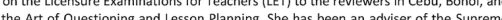
Student Council, the Student Exchange Program, and currently, of the ELT Dissertations and Master Thesis. These experiences has made her r recipient of the Most Outstanding Administrator at the Siena School o Uaga, Cebu in $19 \mathrm{~s}$ and also the Mentor/Adviser to the 20195

ISBN: 978-621-419-165-9

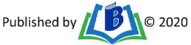

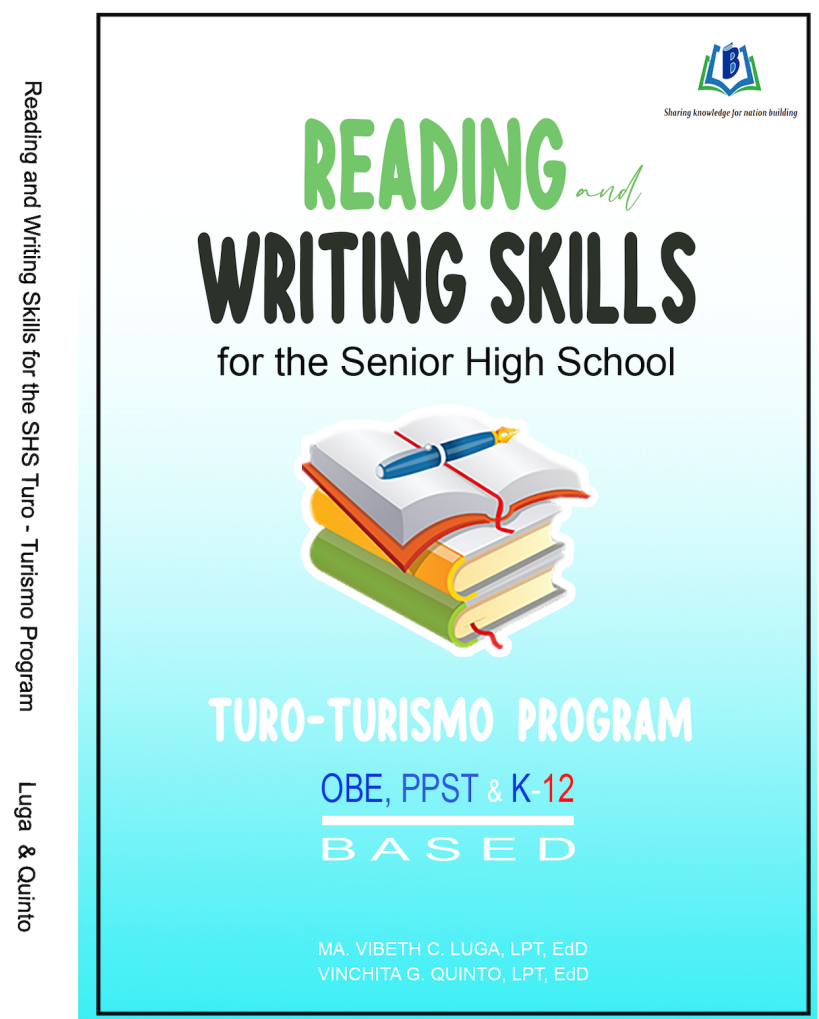




\section{A.2. Lesson 1 Sampler}

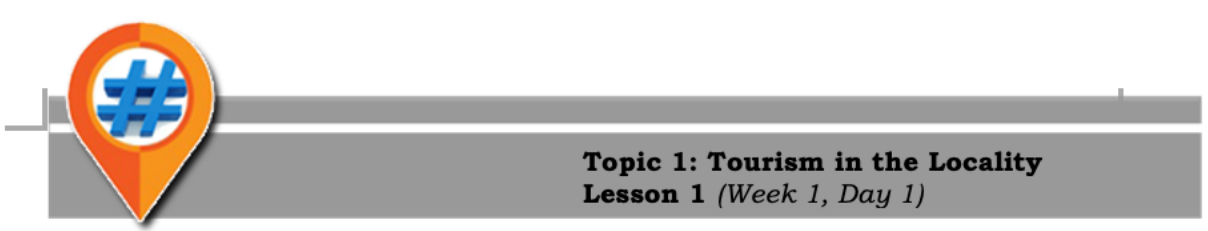

Competency \# 1: Describe a written text as connected discourse.

Objectives:

a. Enumerate three culturally peculiar groups in the locality.

b. Identify the characteristics of a written text as a connected discourse.

c. Design a concept map on the culturally significant things, places, events in the locality.

d. Write about the cultural significance of each selected sites or objects.

\section{Key Concepts}

Written text
anything written or printed to convey meaning to the reader
classified according to the purpose of writing known as the text types such
as describing a place or thing using facts (factual texts), expressing a point of
view to influence or persuade the readers (persuasive texts), and describing
something in an imaginative way (literary texts)
Examples: (factual texts) recipes, manuals, instructions, reports, infographics,
diagrams; (persuasive texts) editorial, scripts in FlipTop, a team's argument for
a debate; (literary texts) stories, scripts for plays, lyrics of a song; and any other
piece of written language such as novena guide, comic strips, digital messages
(text or chat), emails or posters
Discourse
of an intellectual transaction of meaning which comes in overarching modes
of describing, narrating, exposing or making an argument

Activity 1: Culture and Heritage. These people belong to a culturally peculiar group in the province. Can you identify the names of their group?

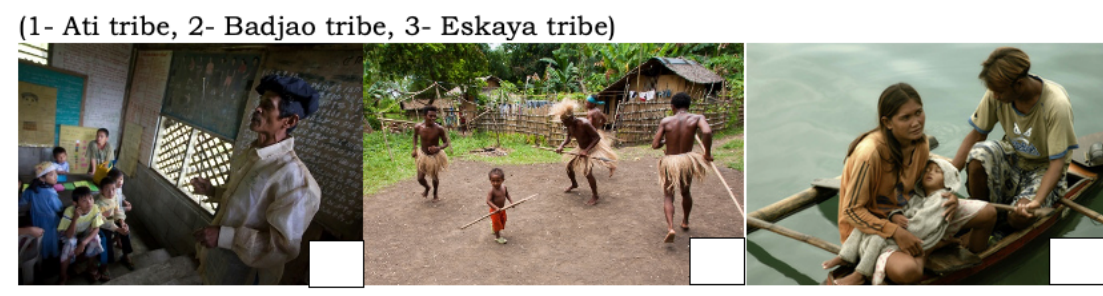

Activity 2:

Reading Text 1: Read this text about Graham's thoughts on multiculturalism in the Philippines. Then, identify the type of text this could be classified. 